\title{
Access to medicines and the TRIPS agreement Recognising extraterritorial human rights obligations
}

Jennifer Sellin

\section{Introduction}

Access to medicines is a human rights issue. Human rights provide the tools for advancing global health by converting moral imperatives into legal entitlements. A total of 171 states worldwide are party to the 1966 International Covenant on Economic, Social and Cultural Rights (ICESCR), which recognises the right of everyone to the enjoyment of the highest attainable standard of physical and mental health (ICESCR, art. 12) and the benefits of scientific progress and its applications (ICESCR, art. 15(1)b). Today the use of medicines is an essential and indispensable part of the treatment of diseases and ill health, and as such a key element of the right to health. States, therefore, have human rights obligations to safeguard the availability and (economic) accessibility of safe, quality medicines, vaccines and other health technologies, such as diagnostic tools and medical equipment. The impact of intellectual property rights (IPRs) in that regard has been an issue of (academic) debate for over two decades (Committee on Economic, Social and Cultural Rights (CESCR) 2020, paras. 58-62; 't Hoen 2016; Sellin 2014; Forman 2011; Matthews 2010; Hestermeyer 2007; CESCR 2006, para. 35; United Nations Commission on Human Rights 2001).

The current biomedical research and development (R\&D) model incentivises innovation by rewarding inventors with a time-limited market monopoly for producing, using and selling their end product. These monopoly rewards, enforced through IPRs, effectively prevent competition and enable the owner to largely set the price and production terms of its product. IP is argued to stimulate innovation by allowing medicines developers to recoup their investments in $\mathrm{R} \& \mathrm{D}$. These same incentives, however, tend to draw medicines to the market for 'profitable' diseases, characterised as affecting large and/or wealthy populations with certainty.

With 164 members the World Trade Organisation's (WTO) adoption of the Agreement on Trade-Related Aspects of Intellectual Property Rights (TRIPS) has significantly influenced the international IP regime and the current biomedical R\&D model as it provides minimum standards for the protection of intellectual property (IP). TRIPS demands that patent 
protection must be available for any inventions that meet the conditions (novelty, inventiveness and capability of industrial application), including for biomedical and pharmaceutical products and processes, giving the patent-holder a monopoly position for at least 20 years. Although the 2001 Doha Declaration on the TRIPS Agreement and Public Health asserted that TRIPS 'can and should be interpreted and implemented in a manner supportive of WTO members' right to protect public health and, in particular, to promote access to medicines for all' (WTO Ministerial Conference 2001, para. 4), tension continues to arise between the international legal regime for the protection of IP and states' human rights obligation to secure access to affordable medicines.

Even though international (human rights) law places the primary responsibility on the state for realising access to medicines for its population within its territory, it is increasingly acknowledged that health is a global and shared responsibility. This chapter starts from the basis that states have human rights obligations beyond a state's national borders, so-called extraterritorial human rights obligations (ETOs) to respect, protect and fulfil access to medicines and examines how these should be applied in the context of states' existing TRIPS obligations. It aims to demonstrate that ETOs can act as an important facilitator to achieve universal access to affordable medicines and other health technologies.

\section{Recognising ETOs for access to medicines}

Health, as well as access to medicines, is a global and shared responsibility (CESCR 2000, para. 5; United Nations General Assembly (UN GA) 2015, SDG3; UN Special Rapporteur on the Right to Health 2013, para. 6; Tobin 2011, p. 325; Ooms and Hammonds 2010, p. 32). The Sustainable Development Goals (SDGs) represent an international commitment towards ensuring access to safe, effective, quality and affordable essential medicines and vaccines for all (UN GA 2015, SDG 3.8). However, a 2016 report of the Lancet Commission on Essential Medicines Policies finds that essential medicines pose a central challenge to the sustainable development agenda. Five core challenges are identified: financing, affordability, quality and safety, appropriate use and developing missing essential medicines (Wirtz et al. 2016, pp. 406-408).

States have human rights obligations to ensure that everyone can enjoy access to medicines, most notably under the ICESCR. The CESCR clarifies that medicines should be sufficiently available, economically and physically accessible on a non-discriminatory basis, culturally acceptable and scientifically and medically appropriate and of good quality (CESCR 2000, para. 12; CESCR 2016, paras. 12-21). That requires, amongst others, positive state measures to enable and assist individuals to enjoy access to medicines (i.e. a duty to facilitate), as well as a duty to provide access to medicines when individuals are unable, for reasons beyond their control, to secure these themselves by the means at their disposal (CESCR 2000, para. 37). However, these obligations are qualified in that the Covenant acknowledges the constraints due to limited resources. As such the obligation is one of progressive realisation to the extent of a state's maximum available resources (ICESCR, art. 2(1)).

Moreover, essential medicines are part of the core content of the right to health (CESCR 2000, para. 43(d); CESCR 2016, para. 49(f)), which refers to the right's minimum essential levels without which it would be devoid of any meaning or relevance, and thus establishes a core obligation for state parties to provide such essential medicines (CESCR 1990, para. 10; CESCR 2000, para. 43; CESCR 2016, para. 49). Additionally, the right to benefit from science establishes a core obligation to ensure access to those applications/innovations that are critical to the enjoyment of the right to health (CESCR 2020, para. 52). Such core obligations translate into prioritised state obligations under the Covenant (Forman et al. 2016). 
According to the WHO, essential medicines are those that satisfy the priority healthcare needs of the population. They are selected with due regard to public health relevance, evidence on efficacy and safety and comparative cost-effectiveness.

Essential medicines are intended to be available within the context of functioning health systems at all times in adequate amounts, in the appropriate dosage forms, with assured quality and adequate information, and at a price the individual and the community can afford.

(www.who.int)

For low- and middle-income countries (LMICs), which struggle with (severe) resource constraints and have limited or no local pharmaceutical manufacturing capacity, that can be particularly difficult. Unsurprisingly therefore, the CESCR has repeatedly recognised the essential role of international assistance and cooperation (IAC) for the full realisation of the Covenant's rights (CESCR 1990, paras. 13-14; CESCR 2000, para. 38; CESCR 2006, para. 36; CESCR 2016, para. 50; CESCR 2020, para. 77), emphasising in particular the duties of those states and other actors 'in a position to assist' to 'enable developing countries to fulfil their core obligations' (CESCR 2000, para. 45).

The legal basis for such an obligation of IAC is found in Article 2(1) ICESCR, which commands each state party to take steps towards the progressive realisation of the Covenant's rights, including through international assistance and cooperation, that is, read together with Articles 55-56 of the UN Charter and in light of the ICESCR's object and purpose. As such, it is now recognised that states have health-related ETOs that exist alongside (and separate to) a state's domestic human rights obligations (Yamin 2010; Bueno de Mesquita et al. 2010).Yet, some disagreement and ambiguity remain as to the nature, scope and application of such obligations (Saul 2014, pp. 138-140; Tobin 2011, p. 368). The Maastricht Principles on Extraterritorial Obligations of States in the Area of Economic, Social and Cultural Rights (the Maastricht Principles on ETOs) aim to fill this gap (etoconsortium.org). Although formally non-binding, they are instructive as an interpretive tool and build on the CESCR's interpretation. Moreover, they have increasingly been referred to and used by international human rights bodies (CESCR 2017, footnote 71; UN Special Rapporteur on the Right to Water and Sanitation 2014, para. 70; UN Independent Expert on Foreign Debt 2014, paras. 37-41).

In general terms, states have ETOs to respect, that is, to refrain from interfering with the enjoyment of economic, social and cultural (ESC) rights in other countries (Maastricht Principles on ETOs, paras. 19 et seq.); to protect, that is, to prevent third parties from violating ESC rights in other states, as long as they are able to influence these third parties by way of legal or political means (Maastricht Principles on ETOs, paras. 23 et seq.); and to fulfil, that is, to act separately and jointly through international cooperation to facilitate and provide where necessary ESC rights in other states (Maastricht Principles on ETOs, paras. 28 et seq.; CESCR 2000, para. 39).

ETOs encompass 'obligations relating to the acts and omissions of a state [...] that have effects on the enjoyment of human rights outside that state's territory' (Maastricht Principles on ETOs, para. 8(a)). In today's globalised and interdependent world, state conduct can, and regularly does, affect individuals' access to (essential) health technologies both within and beyond a country's borders. For example, especially during the early stages of the COVID-19 pandemic, many countries responded to acute shortages of personal protective equipment (PPE), medicines and other medical equipment by imposing export restrictions to bolster domestic supplies. As a result, especially LMICs were left with few options to secure essential medical supplies in their 
fight against the pandemic. Another concern is that of 'vaccine nationalism', where governments have entered into pre-purchase agreements with COVID-19 vaccine developers to secure doses for their own population ahead of other countries, which has made the first developed vaccine(s) mainly available to rich countries, leaving vulnerable populations in LMICs behind.

The next section examines how international IP regimes, particularly the TRIPS Agreement, may impede access to medicines and negatively impact states' ability to comply with their human rights obligations.

\section{Access to medicines \& the TRIPS agreement}

There are many reasons why patients lack adequate access to medicines. The problem is particularly prevalent in LMICs, disproportionately affecting the world's poor and marginalised. It is impossible to address all of these here, which is why this chapter focuses on two central issues as also indicated by the 2016 Lancet Commission report: affordability and missing essential medicines (Wirtz et al. 2016, pp. 406-408).

First, medicine pricing may significantly impact the (economic) accessibility of (essential) medicines. Especially in countries without a well-organised, well-functioning healthcare system where the majority of patients have to pay for their healthcare privately, the cost of medicines can easily become too burdensome. Most LMICs, having limited (financial) resources, struggle to facilitate and, if necessary, provide medicines to their population as this places a considerable burden on their healthcare budgets. That affordability poses a key challenge for access is wellrecognised (Wirtz 2016, p. 421 et seq.; United Nations Secretary General's (UN SG's) HighLevel Panel on Access to Medicines 2016, p. 15; 't Hoen 2016, p. 114).

The issue hit a high point at the height of the HIV/AIDS pandemic in the 1990s when antiretroviral medicines (ARVs) were first introduced but at a price of over US\$10,000 per patient per year (p.p.p.y) that meant they were inaccessible to the majority of patients who needed them. These ARVs, as most new medicines are, were protected by IPRs such as patents. Patents are time-bound monopoly rights that grant the patent-holder the exclusive right to make, use and sell the patented invention. In the early 2000s, pharmaceutical companies, mostly from India, started offering generic versions of ARVs at significantly lower prices. Generic medicines are non-patented medicines that are equivalent to an existing approved brand name and patented medicine. They work in the same way and provide the same clinical benefits as the patented medicine. As such, the CESCR recommends that safe and effective generic medicines should be prioritised over expensive brand name products so as to make effective use of limited resources (UN CESCR 2020, para. 70). Due to concerns over access to low-cost medicines, India's 1970 Patents Act did not grant product patents for medicines, allowing it to develop a booming generic pharmaceutical industry. Yet, with the establishment of the WTO in 1995, India was now automatically bound by the TRIPS Agreement, although it did not have to grant and enforce patents for medicines until the end of TRIPS' transition period for developing countries in 2005. While implementing TRIPS' standards, India also purposefully used the flexibility in TRIPS to balance public health interests with IP protection, for example, through its introduction of Section 3(d) to prevent so-called 'evergreening', that is, the extension of patent protection for 'new inventions' that are essentially slight modifications of already existing medicines. To this day, India is seen as the 'pharmacy of the developing world' (Lee 2015, pp. 108-114). Generic competition has brought prices for standard HIV treatment down by $99 \%$ to around US $\$ 100$ p.p.p.y. However, India's patent law has long been a target for the multinational pharmaceutical industry backed by the US and EU among others (MSF Access Campaign, n.d.). 
A second issue that disproportionately affects access in LMICs is that of missing essential medicines or the unavailability of treatments options for so-called neglected and povertyrelated diseases. Neglected diseases are those diseases that affect almost exclusively poor people in LMICs and for which health interventions and R\&D are inadequate to the need (UN SG High-Level Panel on Access to Medicines 2016, p. 13; 't Hoen 2016, pp. 121-122). Examples include neglected tropical diseases such as Chagas disease and Leishmaniasis, but also multi-drug resistant tuberculosis (MDR-TB). For example, each year 500,000 people develop MDR-TB, with only $1 / 9$ cases being successfully treated (www.stoptb.org). Even though TB is one of the top infectious diseases worldwide, most advances in treatment still come from recycling medicines first developed in the 1940s-1960s. In nearly 50 years, only few new medicines have been approved for treating MDR-TB and access to these has remained extremely limited. Investment in TB research continues to fall short of what is estimated to be required (Frick 2016).

The privatisation of science that has been prevalent during the last decades, especially in the biomedical and pharmaceutical field, has significantly impacted the manner in which science is conducted, facilitated and promoted and the role of the state in that regard. Economic globalisation, the increase and strengthening of global institutions such as the WTO and the growth of large and powerful multinational corporations have all played a role. Private corporations dominate the pharmaceutical sector and are major actors in pharmaceutical and biomedical R\&D and innovation. As a result, the majority of private health-related R\&D is profit-driven and invested in medicines and treatments with substantial guaranteed returns. However, extensive $\mathrm{R} \& \mathrm{D}$ targeted at diseases overwhelmingly prevalent in LMICs is missing. IPRs play a crucial role in that process. Moreover, significant disparities among states are increasing with respect to the availability of resources, capabilities and infrastructure necessary to engage in biomedical and pharmaceutical innovation and production, and thus widening the divide between the most and least scientifically and technologically developed states.

IPRs can, therefore, negatively impact the short- and long-term availability and accessibility of (essential) medicines. Especially in LMICs unsuitably high standards of IP protection are problematic because they ignore developing countries' specific local needs, technological abilities and public health conditions (Yu 2018, p. 9). However, most states are not free to design and implement a national IP regime that suits their needs best, since they are members of the WTO and therefore automatically bound by the TRIPS Agreement. As such TRIPS has widespread membership throughout the world, and, as opposed to previous conventions dealing with IP, is the first international instrument to set out minimum standards of IP protection and subject to the WTO dispute settlement mechanism.

Article 27 introduced one of the major achievements of the TRIPS Agreement, namely the extension of patent protection to all fields of technology. As a result, members can no longer exclude medicines or other health technologies from patent protection. Articles 28 and 33 TRIPS oblige members to grant patent-holders a set of exclusive rights (i.e. to prevent third parties from making, using, offering for sale, selling or importing for these purposes the patented product without consent) for a minimum period of 20 years. The monopolies created through patent protection can result in unduly expensive medicines and as such interfere with individuals' access to affordable medicines. Moreover, IP protection can create distortions in the funding of biomedical and pharmaceutical $R \& D$ with an undue focus on profit-making, rather than addressing the public health needs of the world's most poor and marginalised (CESCR 2020, paras. 60-61). As such, the TRIPS' minimum standards have a very real effect on (developing) members' ability to comply with their human rights obligations to ensure that (essential) medicines and health technologies are adequately available, accessible and affordable (UN SG's High-Level Panel on Access to Medicines 2016, p. 17). 
At the same time, TRIPS also provides for flexibility as its object and purpose is not limited to the protection of IPRs only, but recognises the need to find a balance between IP protection and access, and between the needs of highly developed and developing and least developed countries (TRIPS, preamble and arts. 7 and 8; Seuba 2016, pp. 479-480). That was confirmed by the 2001 Doha Declaration on the TRIPS Agreement and Public Health which asserts that TRIPS 'can and should be interpreted and implemented in a manner supportive of WTO members' right to protect public health and, in particular, to promote access to medicines for all' (WTO Ministerial Conference 2002, para. 4). For example, TRIPS leaves members free to determine the appropriate method of implementation within their national legal systems as long as TRIPS' minimum standards are guaranteed (TRIPS, art. 1). Many of its provisions allow for a degree of interpretative flexibility, such as the term 'novelty' and 'inventive step' found in Article 27 TRIPS. These can be interpreted and implemented in a manner conducive to public health as, for example, India has done with its introduction of Section 3(d) to the Patents Act. Furthermore, TRIPS allows for some concrete tools to strike a fair balance between IP protection and access, such as the regulatory review exception and compulsory licensing (TRIPS, arts. 30-31). Originally, TRIPS limited the use of compulsory licensing to 'predominantly for the domestic market' (TRIPS, art. 31(f)) making it difficult for countries without local manufacturing capacity to import low-cost medicines and as such seriously undermining the usefulness of compulsory licensing for LMICs. The Doha Declaration promised to find a solution to this problem in its Paragraph 6. After tough negotiations, the WTO Decision of 30 August 2003 established a process to allow compulsory licensing for export on a case-by-case basis (WTO General Council 2003). This was followed by an amendment to the TRIPS Agreement in 2005 that took effect 23 January 2017 (TRIPS, art. 31bis).

Besides, in recognition of their special needs and economic, financial and administrative constraints, least-developed WTO members are exempted from implementing the substantive obligations for protection and enforcement of IPRs contained in the TRIPS Agreement until 2021. For pharmaceutical products specifically, least-developed members have until 2033 or when a particular country ceases to be in the least-developed category. These extensions have been granted through the TRIPS Council (TRIPS, art. 66.1), the body responsible for monitoring the operation of the TRIPS Agreement (TRIPS, art. 68).

The interface between TRIPS and the right to health has been comprehensively addressed in the context of access to medicines and will not be repeated here ('t Hoen 2016; Sellin 2014; Hestermeyer 2007). However, a brief mention should be made of the right to benefit from science, which according to the CESCR is a significant mediator between the right to health and IP protection (CESCR 2020, para. 69). The right to benefit from science has a complex relationship with IP protection regimes (UN CESCR, 2020, para. 60). Namely, on the one hand, IP protection is commonly justified because it is supposed to create incentives to innovate, while on the other hand, IP protection can also negatively affect the advancement of science and access to its benefits. A further complicating dimension is the link between IPRs and the right to the protection of the moral and material interests resulting from any scientific, literary or artistic production of which s/he is the author as found in Article 15(1)c ICESCR. However, contrary to human rights, which are derived from the inherent dignity and worth of all persons, IPRs are legal entitlements of a temporary nature that can be revoked, licenced or assigned to someone else. They primarily protect business and corporate interests and investments. They are tools by which states seek, among other things, to provide incentives for inventiveness and creativity and encourage the dissemination of innovations (CESCR 2006, paras. 1-2). IPRs should, therefore, not be equated with the right to benefit from the protection of the moral and material interests of the author (CESCR 2006, paras. 3 and 7). 'Ultimately, [IP] is a social product and has a social 
function. States parties thus have a duty to prevent unreasonable high costs for access to essential medicines' (CESCR 2006, para. 35; CESCR 2020, para. 62). That means striking an adequate balance between IP protection and the availability and (economic) accessibility of scientific knowledge and its benefits/applications (CESCR 2020, para. 62).

Consequently, TRIPS indirectly interferes with the rights to health and benefit from science where it undermines individuals' access to medicines. Not only do states have domestic human rights obligations to secure access to safe, quality, affordable medicines, for example, by making full use of the TRIPS flexibilities, but they also have ETOs to do so. What such ETOs could entail will be further examined in the next section.

\section{Identifying ETOs for access to medicines}

This section will attempt to demonstrate the value and importance of health-related ETOs to facilitate and contribute to achieving universal access to medicines, by providing an illustration of the nature and type of states' ETOs to safeguard access to affordable (essential) medicines in the context of states'TRIPS obligations. These examples are by no means an exhaustive analysis of states' ETOs in this context, but aim to demonstrate that it is neither impossible nor unworkable to identify a range of different, relatively specific types of ETOs for access to medicines. Even though the following examples are presented as separate obligations, there may be a degree of overlap between them in practice.

\section{ETOs related to TRIPS}

- WTO members should not engage in any conduct in the WTO that nullifies or impairs individuals' access to medicines in any (other) state, or a state's ability to comply with their access to medicines obligations. States should desist from actions or omissions that nullify or impair the enjoyment of access to medicines outside their territories (Maastricht Principles on ETOs, para. 20), as well as impairs the ability of another state to comply with its access to medicines obligations (Maastricht Principles on ETOs, para. 21). Specifically, as members of international organisations, states must take all reasonable steps to ensure that the organisation acts consistently with the human rights obligations of that state (Maastricht Principles on ETOs, para. 15).

For example, WTO members should not oppose requests from least-developed members to the TRIPS Council, which is open to all WTO members, to extend the transition period for TRIPS allowing them to forego the protection and enforcement of IPRs until their economies are stronger. In October 2020, Chad, on behalf of the LDC group, submitted such a request pointing to the difficulties that LDCs continue to face in reaching their development goals, which have been further aggravated by the COVID-19 pandemic. Unlike the previous extensions, the present request does not set a specific date for all LDCs for the termination of the transition period. Rather, it proposes establishing the extension for as long as a member remains a LDC and following graduation for a defined period of 12 years (WTO TRIPS Council 2020a).

- (Developed) states should not engage in conduct that impairs the ability of WTO members to make full use of the TRIPS flexibilities. States should elaborate, interpret and apply international agreements in a manner consistent with their human rights obligations (Maastricht Principles on ETOs, para. 17). According to the CESCR that requires that 'the right to health is given due attention in international agreements' (CESCR 2000, para. 39), meaning that states parties should take steps to ensure that their bilateral, regional or international agreements dealing with IP do not impede access to medicines and incorporate to the fullest extent any safeguard and flexibilities 
to secure this (CESCR 2016, para. 51). States parties should identify any potential conflicts between the ICESCR and IP agreements and, in case a conflict is found, refrain from entering into such treaties (CESCR 2017, para. 13), as well as review their existing IP agreements, such as TRIPS, to ensure that they are consistent with their right to health obligations, and amend them as necessary (CESCR 2016, para. 51). For example, the TRIPS Agreement was formally amended in 2017 to allow members producing generic medicines under compulsory licence to export such medicines to LDCs that lack manufacturing capacity (TRIPS, art. $31 \mathrm{bis}$ ). Effectively the provision was already in place since the 2003 WTO decision. Unfortunately, it has not proven to be a very effective tool for LMICs without manufacturing capacity to secure cheap generic medicines and is widely criticised for its complexity ('t Hoen 2016, pp. 45-46).

- WTO members should initiate, promote and assist in adopting and implementing processes, and, where necessary reforms, that enhance systemic coherence between the TRIPS regime and international human rights law. The problems surrounding access to medicines clearly illustrate the tension that exists between (national and international) IP regimes and international human rights. Although the TRIPS Agreement is not strictly incompatible with the ICESCR (Tobin 2011, pp. 357-358), the object and purpose of both treaties differ. The underlying values of the international trade regime and the international human rights regime are distinct, both have different starting points and principal characteristics. There is a lack of explicit human rights references in the WTO Agreement, TRIPS, WTO jurisprudence and even the Doha Declaration on TRIPS and Public Health. The WTO adjudicative bodies can clarify and apply WTO law but are not competent to give direct effect to international human rights law and formally interpret and enforce human rights treaties. However, there is scope to invoke human rights arguments in WTO jurisprudence (Seuba 2016, pp. 481-482; McBeth 2010, p. 163).

States parties to the ICESCR have a duty to 'prevent unreasonable high costs for access to essential medicines' (CESCR 2006, para. 35; CESCR 2020, para. 62). That means striking an adequate balance between IP protection and the availability and (economic) accessibility of (essential) medicines (CESCR 2020, para. 62). In achieving this balance, private or corporate interests should not be unduly favoured over the public interest. Thus, IP protection must not impede a state's ability to comply with their core obligations in relation to the rights to food, education and health (CESCR 2006, para. 35). In the context of their TRIPS obligations, WTO members should therefore initiate, promote and assist in adopting and implementing policies that safeguard that the TRIPS Council and WTO adjudicatory bodies interpret and apply WTO law in conformity with WTO members' human rights obligations. For example, in October 2020, India and South Africa submitted a request to the TRIPS Council to waive certain provisions of the TRIPS Agreement in light of the exceptional circumstances of the COVID-19 pandemic. The communication recognises that 'it is important for WTO Members to work together' to ensure that IPRs 'do not create barriers to the timely access to affordable medical products including vaccines and medicines or to scaling-up of research, development, manufacturing and supply of medical products essential to combat COVID-19'. The proposed waiver should continue until widespread vaccination is in place globally (WTO TRIPS Council 2020b).

\section{ETOs related to TRIPS+ agreements}

- (Developed) states should not pressure LMICs to accept TRIPS+ standards. Through the conclusion of free trade and/or investment agreements, high-income countries (HICs) in particular demand more extensive protections for IPRs than strictly required by TRIPS, and therefore named TRIPS+ (Yu 2018, pp. 7-10;'t Hoen 2016, pp. 85-86). Such agreements, among others, 
limit opposition to patent applications, prohibit national regulatory authorities from approving generic medicines until patents have expired, maintain data exclusivity and thereby delay the approval of generic medicines and limit the grounds for compulsory licensing. The negative impact of TRIPS+ agreements on access to affordable medicines is well-documented (UN SG's High-Level Panel on Access to Medicines 2016, pp. 24-26; Wirtz 2016, pp. 424-425). This is, moreover, exacerbated by the most-favoured-nation treatment principle, which, as a cornerstone of the WTO, requires that when granting a favour to one state that should also apply to all other WTO members (TRIPS, art. 4). The result is a development of everincreasing standards of IP protection and fragmentation of the international regulatory system forcing LMICs to spread their scarce resources and personnel over a multitude of fora and negotiations (Yu 2018, p. 11). Consequently, such TRIPS+ arrangements indirectly interfere with the right to health, as they create a real and foreseeable risk of undermining access to affordable medicines in LMICs. Powerful (developed) states should, therefore, not encourage, or place undue pressure on LMICs to accept such TRIPS+ standards (UN Special Rapporteur in the field of Cultural Rights 2015, para. 104; UN Special Rapporteur on the Right to Health 2011, para. 90).

- States should subject TRIPS+ agreements to human rights impact assessments. States must conduct prior assessment of the potential extraterritorial impacts of their practices on the enjoyment of access to medicines (Maastricht Principles on ETOs, para. 14). The effect of TRIPS+ arrangements is exacerbated by the lack of any due diligence undertaken to assess, and if necessary, prevent, any harmful impact of TRIPS+ agreements on access to medicines. One policy tool regularly put forward to remedy this is human rights (or right to health) impact assessments (MacNaughton and Forman 2015, pp. 124 and 127). Such impact assessments allow policymakers and civil society actors to prevent or mitigate any negative impacts of a trade/investment agreement under negotiation on the right to health within or beyond their national territory. They measure the potential impact of the agreement under negotiation on the capacity of states to meet their (extra)territorial access to medicines obligations, as well as individuals' capacity to enjoy their rights.

\section{Additional ETOs}

- (Developed) states should, to the extent possible, ensure that the pharmaceutical industry linked to their sphere of control or whose conduct they can influence, does not engage in conduct that impairs the ability of states to realise access to affordable medicines. States must take necessary measures to ensure that non-state actors, which they are in a position to regulate, as well as in a position to influence, do not nullify or impair the enjoyment of access to medicines (Maastricht Principles on ETOs, paras. 24 and 26). Private pharmaceutical corporations are key players in the process of biomedical and pharmaceutical R\&D, innovation and manufacturing, as well as key beneficiaries of IP regimes as they (generally) are the patent-holders of existing or new medicines. Their conduct can therefore significantly impact individuals' access to affordable (essential) medicines, both within and outside a state's borders.

Health emergencies, such as the COVID-19 pandemic, epitomise the need for (scientific and technical) international cooperation and regulation of private actors to ensure that vaccines, therapeutics and diagnostics are developed, if not yet existing, and thereafter made equitably available and accessible. As the CESCR highlights, in a pandemic 'sharing the best scientific knowledge and its applications, especially in the medical field, becomes crucial to mitigate the impact of the disease, and to expedite the discovery of effective treatments and vaccines' (CESCR 2020, para. 82). 
The pricing of pandemic health products together with global manufacturing capacity are key determinants of their global availability and accessibility. Difficult allocation and rationing decisions can be eased through price reductions and increasing production capacity, including through non-exclusive licencing. Especially if governments have spent enormous amounts of public financing on R\&D for new pandemic health technologies, they should leverage their positions as financiers to, for example, set the pricing terms of the end product, or require pharmaceutical and biomedical companies to voluntarily licence their IPRs on a non-exclusive and global basis. For example, in the context of the COVID-19 pandemic, the WHO launched the COVID-19 Technology Access Pool at the end of May 2020 on the initiative of Costa Rica. The proposed voluntary pool aims to collect patent rights, regulatory test data and other information that could be shared for developing medicines, vaccines and diagnostics to combat COVID-19 (www.who.int). The pharmaceutical industry, however, has opposed the effort (Silverman 2020).

In conclusion, all these examples of ETOs, in essence, come down to a general obligation for states to create an international enabling environment conducive to the universal fulfilment of the right of everyone to have access to (essential) medicines (Maastricht Principles on ETOs, para. 29; Tobin 2011, p. 344). In the words of the CESCR, states must, therefore, 'recognise the essential role of international cooperation' to fully realise the right to health (CESCR 2000, para. 38) and 'take steps through legislation and policies, including diplomatic and foreign relations, to promote an enabling global environment for the advancement of science and the enjoyment of the benefits of its applications' (CESCR 2020, para. 77).

\section{Concluding remarks}

Access to medicines is a global and shared responsibility. However, state conduct can and does affect individuals' access to (essential) medicines and health technologies both within and beyond a country's borders. International IP regimes such as the TRIPS Agreement may have such an effect. The monopolies created through patent protection can result in expensive medicines unduly restricting individuals' (economic) access to such patent protected products. Moreover, IP protection can create distortions in the funding of biomedical and pharmaceutical R\&D with an undue focus on profit-making, rather than addressing the public health needs of the world's most poor and marginalised. In such cases, TRIPS indirectly interferes with the rights to health and benefit from science as it undermines individuals' access to medicines and negatively impacts (developing) members' ability to realise access to safe, quality and affordable (essential) medicines and health technologies.

In light of the rights to health and benefit from science, states have a range of different domestic and extraterritorial human rights obligations to respect, protect and fulfil access to medicines. Consequently, this chapter examined how such ETOs should be applied in the context of states' TRIPS obligations. The list of ETOs provided is intended as an illustration of the nature and type of states' ETOs in this context, but is by no means an exhaustive analysis. It demonstrates that it is neither impossible nor unworkable to identify a range of different, relatively specific types of ETOs for access to medicines. Moreover, it strengthens the importance and value of ETOs as a facilitator to achieve universal access to medicines for all. Now is the time to deepen and extend the analysis of the nature, scope and practical application of ETOs in relation to international IP regimes and in that context also focus on other areas of IP protection (copyright, indigenous knowledge, etc.) beyond access to medicines. Moreover, issues of accountability, remedies and enforcement mechanisms remain to be addressed. 


\section{References}

Bueno de Mesquita, J. et al. (2010) 'The Human Rights Responsibility of International Assistance and Cooperation in Health' in Gibney, M. and Skogly, S. (eds). Universal Human Rights and Extraterritorial Obligations, University of Pennsylvania Press.

Committee on Economic, Social and Cultural Rights (CESCR) (1990) GC 3 on the Nature of States Parties Obligations, E/1991/23, E/C.12/1990/8, annex III.

(2000) GC 14 on the Right to the Highest Attainable Standard of Health, E/C.12/2000/4.

(2006) GC 17 on the Right of Everyone to Benefit from the Protection of the Moral and Material Interests Resulting from any Scientific, Literary or Artistic Production of which He or She is the Author, E/C.12/GC/17.

(2016) GC 22 on the Right to Sexual and Reproductive Health, E/C.12/GC/22.

(2017) GC 24 on State Obligations under the International Covenant on Economic, Social and Cultural Rights in the Context of Business Activities, E/C.12/GC/24.

(2020) GC 25 on Science and Economic, Social and Cultural Rights, E/C.12/GC/25.

etoconsortium.org (n.d.) Maastricht Principles on Extraterritorial Human Rights Obligations of States in the Area of Economic, Social and Cultural Rights, available at https://www.etoconsortium.org/nc/en/ main-navigation/library/maastricht-principles/?tx_drblob_pi1\%5BdownloadUid $\% 5 \mathrm{D}=23$ [accessed 26 November 2020].

Forman L. (2011) 'An Elementary Consideration of Humanity? Linking Trade-Related Intellectual Property Rights to the Human Right to Health in International Law', The Journal of World Intellectual Property, 14(2), 155-175.

Forman, L. et al. (2016) 'Conceptualising Minimum Core Obligations under the Right to Health: How Should we Define and Implement the "Morality of the Depths"”, The Journal of Human Rights 20(4), 531-548.

Frick M. et al. (2016) 'Falling Short of the Rights to Health and Scientific Progress: Inadequate TB Drug Research and Access', Health and Human Rights Journal 18(1), 9-23.

Hestermeyer, H. (2007) Human Rights and the WTO. The Case of Patents and Access to Medicines, Oxford University Press.

Lee, J-H. (2015) A Human Rights Framework for Intellectual Property, Innovation and Access to Medicines, Routledge.

MacNaughton, G. and Forman, L. (2015) 'Human Rights and Health Impact Assessments of Trade-Related Intellectual Property Rights: A Comparative Study of Experiences in Thailand and Peru', Journal of Human Rights 14(1), 124-148.

Matthews, D. (2010) 'Intellectual Property Rights, Human Rights and the Right to Health' in Grosheide, W. (ed). Intellectual Property Rights and Human Rights: A Paradox, Edward Elgar.

McBeth, A. (2010) 'Human Rights in Economic Globalisation' in Joseph, S. and McBeth, A. (eds). Research Handbook on International Human Rights Law, Edward Elgar.

MSF Access Campaign (n.d.) 'Affordable Medicines from India under Attack: What's at Stake', https:// msfaccess.org/spotlight-pharmacy-developing-world [accessed 26 November 2020].

Ooms, G. and Hammonds, R. (2010) 'Taking Up Daniels' Challenge: The Case for Global Health Justice', Health and Human Rights Journal 12(1), 29-46.

Saul, B., Kinley, D. and Mowbray, J. (2014) The International Covenant on Economic, Social and Cultural Rights. Commentary, Cases and Materials, Oxford University Press.

Sellin, J. (2014) Access to Medicines. The Interface between Patents and Human Rights. Does One Size Fit All?, Intersentia.

Seuba, X. (2016) 'Human Rights and Intellectual Property' in Yusuf, A.A. and Correa, C.M. (eds). Intellectual Property and International Trade. The TRIPS Agreement, Kluwer Law International.

Silverman, E. (2020) Pharma Leaders Shoot Down WHO Voluntary Pool for Patent Rights on COVID19 Products, STAT, available at https://www.statnews.com/pharmalot/2020/05/28/who-voluntarypool-patents-pfizer/ [accessed 26 November 2020]. 
STOPTB (n.d.) 'Factsheets \& Information Brochures', http://www.stoptb.org/resources/factsheets/ [accessed 26 November 2020].

't Hoen, E. (2016) 'Private Patents and Public Health. Changing Intellectual Property Rules for Access to Medicines', Health Action International, available at http://accesstomedicines.org/resources [accessed 26 November 2020].

Tobin, J. (2011) The Right to Health in International Law, Oxford University Press.

UN Special Rapporteur in the field of Cultural Rights (2015) Report of the Special Rapporteur in the Field of Cultural Rights, F. Shaheed, A/70/279.

UN Special Rapporteur on the Right to Health (2011) Report of the Special Rapporteur on the Right of Everyone to the Enjoyment of the Highest Attainable Standard of Physical and Mental Health, A. Grover. Addendum, Mission to Guatemala, A/HRC/17/25/Add.2.

(2013) Report of the Special Rapporteur on the Right of Everyone to the Enjoyment of the Highest Attainable Standard of Physical and Mental Health on Access to Medicines, A. Grover, A/ $\mathrm{HRC} / 23 / 42$.

(2016) Report of the Special Rapporteur on the Right of Everyone to the Enjoyment of the Highest Attainable Standard of Physical and Mental Health, D. Puras, A/71/304.

UN Special Rapporteur on the Right to Water and Sanitation (2014) Report of the Special Rapporteur on the Human Rights to Safe Drinking Water and Sanitation, C. de Albuquerque, A/HRC/27/55.

United Nations (UN) (2014) Independent Expert on Foreign Debt: Final Report of the Independent Export on the Effects on Foreign Debt and other Related International Financial Obligations of States on the Full Enjoyment of All Human Rights, particularly Economic, Social and Cultural Rights, C. Lumina, A/HRC/25/52.

United Nations Commission on Human Rights (UN CionHR) (2001) Economic, Social and Cultural Rights. Globalisation and Its Impact on the Full Enjoyment of Human Rights. Progress Report Submitted by J. Oloka-Onyango and Deepika Udagama in Accordance with Sub-Commission Resolution 1999/8 and Commission on Human Rights Decision 2000/102, E/CN.4/2001/10.

United Nations General Assembly (UN GA) (2015) Transforming Our World:The 2030 Agenda for Sustainable Development, UNGA Res 70/1.

United Nations Secretary General's (UNSG's) High-Level Panel on Access to Medicines (2016) 'Promoting Innovation and Access to Health Technologies', Secretariat hosted by the United Nations Development Programme, available at http://www.unsgaccessmeds.org/final-report [accessed 26 November 2020].

Wirtz,V.J., Hogerzeil, H.V. and Gray, A. et al. (2016) 'The Lancet Commission on Essential Medicines Policies: Essential Medicines for Universal Health Coverage', Lancet 389, 403-476.

World Trade Organisation (WTO) (2001) Ministerial Conference: Doha Declaration on the TRIPS Agreement and Public Health. Adopted at the Doha Ministerial Conference, Fourth Session, WT/MIN(01)/DEC/2.

WTO General Council (2003) Implementation of Paragraph 6 of the Doha Declaration on the TRIPS Agreement and Public Health, WT/L/540.

WTO TRIPS Council (2020a) Extension of the Transition Period under TRIPS Article 66.1 for Least Developed Country Members. Communication from Chad on Behalf of the LDC Group, IP/C/W/668. (2020b) Waiver from Certain Provisions of the TRIPS Agreement for the Prevention, Containment and Treatment of COVID-19. Communication from India and South Africa, IP/C/W/669.

WHO (n.d.) 'COVID-19 Technology Access Pool', https://www.who.int/emergencies/diseases/novelcoronavirus-2019/global-research-on-novel-coronavirus-2019-ncov/covid-19-technology-accesspool [accessed 26 November 2020].

(n.d.) 'Essential Medicines', https://www.who.int/topics/essential_medicines/en/ [accessed 26 November 2020].

Yamin, A.E. (2010) 'Our Place in the World: Conceptualising Obligations Beyond Borders in Human Rights-Based Approaches to Health', Health and Human Rights Journal 12(1), 3-14.

Yu, P.K. (2018) 'Realigning TRIPS-Plus Negotiations with UN Sustainable Development Goals', Texas A\&M University, School of Law. Legal Studies Research Paper Series 18(40), 1-19. 